\title{
COMPARATIVE GROWTH PERFORMANCE AND ACTIVITY OF DEFENSE RELATED ENZYMES AND GENE EXPRESSION IN RUBBER CLONES AGAINST RIGIDOPORUS MICROPORUS INFECTION
}

\author{
Afdholiatus Syafaah ${ }^{1}$, Natthakorn Woraathakorn ${ }^{2}$, Patimapon Plodpai ${ }^{1}$, Charassri Nualsri ${ }^{1}$ and \\ Korakot Nakkanong*1, \\ ${ }^{1}$ Department of Natural Rubber Production, Technology and Management (International Program), \\ Faculty of Natural Resources, Prince of Songkla University, Hatyai, Songkhla, Thailand, 90112 \\ ${ }^{2}$ Faculty of Science and Technology, Prince of Songkla University, Pattani Campus Pattani, \\ Thailand, 94000.*Email: korakot_nick@yahoo.com
}

Article received 24.07.2020, Revised 24.09.2020, Accepted 28.09.2020

\begin{abstract}
Rigidoporus microporus is the causal agent of rubber white root disease (WRD). Control of this is commonly carried out by chemical treatment. The use of tolerant rootstocks may present an effective method to lessen its impact. The screening of rubber rootstocks for tolerance of WRD was investigated by both defense-related enzymes and gene expression, and assessment of disease symptoms. Two recommended clones in Thailand (RRIT251 and RRIT408) and RRIM623 (Malaysian clone) were screened and compared with susceptible clones (RRIM600 and BPM24) and tolerant clone (PB5/51) by inoculating young rubber seedling with $R$. microporus. The expression of $P R s$ and $P A L$ were analyzed at $0,1,3,5$, and 7 days post inoculation (dpi) along with the defense-related enzyme activities. Based on observed transcriptional level of $P R s$ and $P A L$ genes, CHI, PAL, and POD enzyme activities, and also evidence from WRD symptom assessment in the field, we concluded that PB 5/51 had the best tolerance with the lowest disease incidence, high PAL and POD enzyme activities, with the next best being RRIM 623 and RRIT 251, respectively. Meanwhile, BPM 24, RRIM 600, and RRIT 408 clones are moderately susceptible to WRD. The study introduces new possibilities for the control of WRD using alternative rubber rootstock clones.
\end{abstract}

Keywords Hevea brasiliensis, $P R$ genes, $P A L$ gene, chitinase, peroxidase, Rigidoporus microporus

\section{INTRODUCTION}

Rubber trees are the main source of commercial natural rubber that mainly used for tires, surgeons' gloves, condoms, balloons and other relatively high-value products. Nowadays, variability of climate change has been recognized as an important factor for root disease breakout such as brown root disease, red root disease and white root disease (Wattanasilakorn et al., 2017). Among the root diseases, white root disease (WRD) caused by Rigidoporus microporus is a worldwide serious problem that can deplete the productivity of the natural latex and lead to massive death of the rubber trees (Nandris et al., 1987). It was found that $95 \%$ of root diseases found in rubber tree plantation in the South of Thailand were identified as white root rot disease (Rojsujit et al., 2011). The pathogen penetrates the root, colonizes the tissues, and degrades the host's cell structure. Rhizomorphs and infection sites remain below ground and a decaying tree do not show visible aerial symptoms, until the roots are severely damaged, followed by appearance of reddish brown basidiocarps on the collar of trees (Ogbebor et al. 2013a). In Indonesia and Malaysia, WRD attacks rubber plantations with disease severity ranging from moderate to severe (Pawirosoemardjo et al.,1992;Farid et al., 2009). According to Ogbebor et al. (2013b), the yield losses on old rubber plantations were up to $50 \%$. In Southern
Thailand, Nissapa and Chuenchit (2011) reported that WRD in rubber plantations caused economic losses of around 4,940-96,177 dollar per hectare. Nandris et al. (1987) reported that root decaying pathogens caused more than $50 \%$ mortality in old stands established after forests were cleared manually; if one assumes 25 years of productive life for a rubber tree, losses came to several hundred thousand dollars per hectare. Current control approaches involve the use of chemical and biological controls, however none have proven to be fully effective. Breeders are working to develop WRD-tolerant rootstocks, which is one of the most promising avenues to a cure. Moreover, rubber tree improvement has been achieved by incorporating new sources of genetic variability to disease resistance against WRD. Therefore, the rubber germplasm accessions have to be characterized for the disease tolerant level. These programs, focusing on disease tolerant level can be speeded up and made more effective by the use of both growth performance after infection and the defense-related gene expression or enzyme activities as selection criteria.

Plants protect themselves from pathogen by constitutive and inducible defense mechanisms (Ferreira et al., 2007). Active or inducible mechanisms include accumulation of phytoalexins, oxida- 
tive burst, systemic acquired resistance (SAR) by accumulations of pathogenesis-related (PR) proteins, and activated transcription of genes encoding enzymes in the biosynthesis of phenolic compound, such as phenylalanine ammonia lyase (PAL) (Montesinos, 2000). According to previous studies, Woraathasin et al (2017a) mentioned that $\mathrm{HbP}$ $R I b$ and $H b P R 3$ were potential defense genes, distinguishing between tolerant and susceptible rubber clones to WRD. Additionally, Sangsil et al (2016) suggested that the $H b P A L$ gene may play a role in the molecular defense response of rubber tree to WRD infection and could be used as a selection criterion for disease tolerance.

Various defense responses combine several factors, such as defense-related enzymes linked to the PR proteins, and the enzyme accumulation prevents infections by pathogens. Defense-related enzymes such as PAL, POD (peroxidase) and CHI (chitinase) are reported to have significantly increased levels in resistant cultivars during pathogen invasion (Kumar et al., 2017). Increased PAL enzyme activity in tomato is associated with its resistance to bacterial spot disease, and in pepper to infection by Xanthomonas campestris (Chandrasekaran et al., 2017; Kim and Hwang, 2014). POD and SOD activities increased in pepper and tomato infected with the pathogen (Jetiyanon, 2007). CHI accumulated together with GLU upon fungal infection, and these enzymes are responsible for hydrolysis of fungal cell wall components (Xu et al., 2016). Here, we report the screening of two recommended clones in Thailand (RRIT251 and RRIT408), RRIM623 (Malaysian clone) compare with susceptible clones (RRIM600 and BPM24) and tolerant clone (PB5/51) for WRD. The transcription levels of $P R s$ and $P A L$ gene, and activity of CHI, PAL, and POD enzymes were determined after $R$. microporus inoculation at the seedling stage. This first comprehensive characterization of WRD tolerance in rubber tree opens new perspectives of investigating the molecular mechanism of WRD resistance and screening for potential tolerant clones.

\section{MATERIALS AND METHODS}

Plant materials: The rubber seeds were germinated in a sandy bed for 15 days and replanted in polybags filled with fine-loamy soil as the medium. Rubber seedlings with similar performance were used in this research. In the study, three clonal rubber clones including a tolerant clone (PB5/51) and two susceptible clones (RRIM600 and BPM24) were used as the baseline characteristics for disease tolerant level. Three rubber clones consist of two recommended clones in Thailand (RRIT251 and
RRIT408) and RRIM623 (Malaysian clone) were screened, compared with the susceptible clones (RRIM600 and BPM24) and tolerant clone (PB5 /51) by inoculating young rubber seedling with $R$. microporus.

Fungal inoculation preparation: $R$. Microsporus isolate RG15 was provided by the Pest Management Department, Prince of Songkla University. It was isolated from basidiocarps collected from an infected rubber tree. The mycelium was freshly grown on $2 \% \mathrm{w} / \mathrm{v}$ potato dextrose agar (PDA) media for 7 days for use as an inoculum.

Seedling inoculation with $\boldsymbol{R}$. microporus for disease measurement: 4-month old rubber seedlings in plastic pots with three replicates were inoculated. Five hundred $\mathrm{g}$ of mushroom media containing $R$. microporus inoculum were placed near the stem and root, and mixed with top soil medium in which the rubber seedlings grown. The inoculation was conducted for eight months of the research.

Seedling inoculation with $R$.microporus for defense-gene and enzyme activity assay: The rubber seedlings with three replications were inoculated with $R$. microporus following Woraathasin method (Woraathasin et al., 2017a) with some modifications. Inoculation was done by creating $30.0 \mathrm{~mm} \mathrm{x}$ $3.0 \mathrm{~mm}$ wounds on the stem, about $1 \mathrm{~cm}$ from the taproot, using a sterilized surgical blade.The area ready to be inoculated was first surface sterilized with $90 \%$ ethanol and then $30.0 \mathrm{~mm}$ x $5.0 \mathrm{~mm}$ agar with actively growing mycelia was placed on the wounds, and wrapped in plastic. Mock inoculations (negative control treatment) were carried out with sterile PDA agar.The two-month old leaves were harvested from each rubber seedling inoculated with $R$. microporus at $0,1,3,5$, and 7 days post inoculation (dpi), and were kept in liquid nitrogen and stored at $-80^{\circ} \mathrm{C}$ for protein extraction.

Disease measurement: Evaluation of disease infection was conducted according to Soytong and Kaewchai (2014) from 3 to 8 months after inoculation with scores on 1-5 scale: level 1 (healthy, green leaves), level 2 (1-25\% yellow leaves), level 3 (26-50\% yellow leaves), level 4 (51-75\% yellow leaves), and level 5 (76-100\% yellow leaves). The symptoms were assessed visually. Data represented at least three independent replicates.

The data collection as disease index (DI) was recorded every month. Data on the severity of the WRD were statistically compared 8 months after inoculation.

Disease Index $(D I)=\frac{(1 x a)+(2 x b)+(3 x c)+(4 x d)+(5 x e)}{(a+b+c+d+e)} \times \frac{100}{X}$

Where:

$1,2,3,4$, and 5 are infection categories 
$\mathrm{a}, \mathrm{b}, \mathrm{c}, \mathrm{d}$, and e are plants that fall into the infection categories

$\mathrm{X}$ is the highest infection severity category, which is 5

RNA extraction and cDNA synthesis: RNA extraction from rubber leaves was carried out based on Deng et al. (2012) method with modifications. A hundred $\mathrm{mg}$ of sample was frozen in liquid nitrogen and stored at $-80^{\circ} \mathrm{C}$ until use. The frozen leaf tissues were ground to powder and suspended in $10 \mathrm{~mL}$ of CTAB, $100 \mathrm{mmol} / \mathrm{L}$ Tris- $\mathrm{HCl}(\mathrm{pH} 8.0)$, $100 \mathrm{mmol} / \mathrm{L}$ EDTA, $1.4 \mathrm{~mol} / \mathrm{L} \mathrm{NaCl}$ and $5 \%(\mathrm{v} / \mathrm{v})$ $\beta$-mercaptoethanol. The suspension was incubated at $65^{\circ} \mathrm{C}$ for 5 minutes. $680 \mu \mathrm{L}$ of chloroform/ isoamyl alcohol $(24: 1, \mathrm{v} / \mathrm{v})$ was added to the suspension that was then centrifuged at $12,000 \times \mathrm{G}$ for 10 minutes at $4^{\circ} \mathrm{C}$, twice. The supernatant was transferred to another tube, and $1 / 3$ volume of $8 \mathrm{~mol} / \mathrm{L}$ $\mathrm{LiCl}$ was added in the crude sample, mixed well and stored at $-20^{\circ} \mathrm{C}$ for $4-16$ hours. The sample was centrifuged at $12,000 \times \mathrm{G}$ for 20 minutes at $4^{\circ} \mathrm{C}$. The crude pellet was transferred to another new tube, $100 \mu \mathrm{L}$ of isopropanol was directly added and the sample was stored at $-20^{\circ} \mathrm{C}$ for 30 minutes. The pellet was centrifuged at $12,000 \times \mathrm{G}$ for 20 minutes at $4^{\circ} \mathrm{C}$. The final pellet was washed with $70 \%(\mathrm{v} / \mathrm{v})$ of ethanol, and air-dried. $1 \%$ formaldehyde agarose gel electrophoresis was used to check the integrity and purity of the isolated RNA. RNA quantification through UV-visible spectrophotometer. cDNA was synthesized by reverse transcription from $1000 \mathrm{ng}$ of total RNA using transcriptome amplification kit according to the manufacturer's instructions (Thermo Scientific).

$P R s$ and $P A L$ gene expression analysis: $P R s$ and $P A L$ primers used in the study are shown in Table 1. Differential gene expression was determined by qRT-PCR. The PCR mixture was $5 \mu \mathrm{L}$ of SYBR green buffer, $1 \mu \mathrm{L}$ of $3 \mu \mathrm{M}$ of primer forward, 1 $\mu \mathrm{L}$ of $3 \mu \mathrm{M}$ primer reverse, and $2 \mu \mathrm{L}$ of $50 \mathrm{ng}$ cDNA template (50 ng). The qRT-PCR was run in a Light Cycler at $95^{\circ} \mathrm{C}$ for 10 minutes, followed by 40 two-step cycles of PCR, including denaturation at $95^{\circ} \mathrm{C}$ for $15 \mathrm{~s}$, and annealing and polymerization at $60^{\circ} \mathrm{C}$ for $1 \mathrm{~min}$. Three independent biological replicates and two technical repeats per each biological replicate were used for this analysis. The relative gene expression was calculated from the cycle threshold $\left(\mathrm{C}_{\mathrm{T}}\right)$ values and analyzed using two methods (Livak \& Schmittgen, 2001). 18s rRNA was used as internal reference gene for normalization (Li et al., 2011).
Table 1: List of primer sequences used in qRT-PCR

\begin{tabular}{|c|c|c|}
\hline Gene & Direction & Sequence $\left(5^{\prime} \rightarrow 3^{\prime}\right)$ \\
\hline \multirow[t]{2}{*}{ PRla } & Forward & $\begin{array}{l}\text { CAG GTG GTT TGG CGC } \\
\text { AAC TC }\end{array}$ \\
\hline & Reverse & $\begin{array}{l}\text { GGT CGC TGC CCA } \\
\text { ACA AAG TT }\end{array}$ \\
\hline \multirow[t]{2}{*}{$P R 3$} & Forward & $\begin{array}{l}\text { TGGTCAATGTGGGCAA } \\
\text { GCCT }\end{array}$ \\
\hline & Reverse & $\begin{array}{l}\text { GGTGGGTGACCATTGT } \\
\text { CCAGT }\end{array}$ \\
\hline \multirow[t]{2}{*}{ PR5 } & Forward & $\begin{array}{l}\text { TGGACCATTAGTGCTA } \\
\text { CTCGTGGAA }\end{array}$ \\
\hline & Reverse & $\begin{array}{l}\text { TGCATATTCGGCCAAG } \\
\text { GTGTTAGG }\end{array}$ \\
\hline \multirow[t]{2}{*}{$P A L$} & Forward & $\begin{array}{l}\text { GGACATGCTCAAAGTT } \\
\text { GTGG }\end{array}$ \\
\hline & Reverse & $\begin{array}{l}\text { TGCTGGCATTCTTCTC } \\
\text { ATTG }\end{array}$ \\
\hline \multirow[t]{2}{*}{$18 s r R N A$} & Forward & $\begin{array}{l}\text { GTAGAGGATGGTGCCG } \\
\text { ACAAC }\end{array}$ \\
\hline & Reverse & $\begin{array}{l}\text { CCAAACTTCCCCAGTT } \\
\text { ACAAGAA }\end{array}$ \\
\hline
\end{tabular}

Protein extraction: The protein was extracted according to Zhang et al. (2009) with minor modifications. $200 \mathrm{mg}$ of sample leaves was crushed in liquid nitrogen in a mortar. Six ml of $0.1 \mathrm{M}$ phosphate buffer $\mathrm{pH} 7$ was added with $0.1 \mathrm{mM}$ EDTA and $0.1 \mathrm{mM}$ Ascorbic acid to the mortar and ground until fine powder remained, and the mixtue was centrifuged at $12,000 \mathrm{rpm}$ for 15 minutes at $4^{\circ} \mathrm{C}$. Ammonium sulphate (3.366g) was added and mixed slowly until completely dissolved, then centrifuged at $12,000 \mathrm{rpm}$ for 15 minutes at $4^{\circ} \mathrm{C}$. The pellet was re-dissolved with $500 \mu \mathrm{L}$ of $0.1 \mathrm{M}$ phosphate buffer at $\mathrm{pH} 7$ along with $0.1 \mathrm{mM}$ EDTA and $0.1 \mathrm{mM}$ ascorbic acid. The protein content was determined according to Bradford method (Brad-ford, 1976) with BSA as the standard. The absorbance was measured at $595 \mathrm{~nm}$.

Phenylalanine ammonia-lyase (PAL) activity assay: The PAL activity was determined through the conversion rate of L-phenylalanine to transcinnamic acid according to Assis et al. (2001) with minor modifications. The PAL activity assayed was measured by incubation reaction with $200 \mu \mathrm{L}$ of enzyme extract, $500 \mu \mathrm{L}$ of $0.1 \mathrm{M}$ L-phenylalanine and adjusting the final reaction volume to 2 $\mathrm{ml}$ with $0.1 \mathrm{M}$ Tris- $\mathrm{HCl} \mathrm{pH}$ 8.5. The mixture was incubated at $37^{\circ} \mathrm{C}$ for 30 minutes, and reaction was stopped by adding $10 \mu \mathrm{L}$ of $6 \mathrm{~N} \mathrm{HCl}$. The absorbance of the resulting agent of trans-cinnamic acid was measured at $290 \mathrm{~nm}$. The reaction with $0.1 \mathrm{M}$ phosphate buffer $\mathrm{pH} 7$ instead of enzyme extract was used as a blank. The PAL specific activity is expressed in moles of cinnamic acid per hour per $\mathrm{mg}$ of protein (mol. $\mathrm{h}^{-1} \cdot \mathrm{mg}^{-1}$ protein). 
Peroxidase (POD) activity assay: The POD enzyme activity was assayed according to Fajardo et al., (1998) with minor modifications. The mixture reaction containing $10 \mu \mathrm{L}$ of enzyme extract, $20 \mu \mathrm{L}$ of $30 \% \mathrm{H}_{2} \mathrm{O}_{2}, 220 \mu \mathrm{L}$ of $0.3 \%$ (v/v) guaiacol, was diluted with $0.05 \mathrm{M}$ of phosphate buffer at $\mathrm{pH} 7$ to final $1,000 \mathrm{ml}$ volume. The absorbance was read at $470 \mathrm{~nm}$ for 1 minute. The POD specific activity is defined in units that could oxidase $1 \mu \mathrm{mol}$ of guaiacol in 1 minute, and expressed in Unit per $\mathrm{mg}$ of protein (Unit.mg $\left.{ }^{-1} \mathrm{P}\right)$. The POD specific activity was calculated following the formula:

$$
\text { POD activity }=\frac{(\Delta \mathrm{A} / \mathrm{min}) \times \mathrm{T} . \mathrm{V} \times 10^{3}}{\mathrm{~S} . \text { VxAbsorptivityxP }} \text { unit. } \mathrm{L}^{-1}
$$

where as

$$
\begin{aligned}
& \text { T.V = Total reaction volume in } \mathrm{ml} \\
& \text { S.V = Sample volume in } \mathrm{ml} \\
& \text { Absorptivity }=\mathrm{mM} \text { absorptivity of guaiacol at } \\
& 470 \mathrm{~nm}=26.6 \\
& \mathrm{P}=\text { Path length in } \mathrm{cm} \\
& \Delta \mathrm{A} / \mathrm{min} \quad=\text { Slope from equation after } \\
& \text { Absorbance measurement }
\end{aligned}
$$

Chitinase (CHI) activity assay: The $\mathrm{CHI}$ activity was determined by Miller (1959). The mixed reaction buffer containing $100 \mu \mathrm{L}$ of colloidal chitin $(1 \% \mathrm{w} / \mathrm{v}), 150 \mu \mathrm{L}$ of protein extract, and $750 \mu \mathrm{L}$ of $1 \mathrm{M}$ sodium acetate buffer at $\mathrm{pH} 5.0$ was incubated at $37^{\circ} \mathrm{C}$ for 30 minutes. $1 \mathrm{~mL}$ of DNS solution was added into the reaction mixture that was boiled at $100^{\circ} \mathrm{C}$ for 5 minutes. The absorbance was measured at $540 \mathrm{~nm}$. N-acetyl-glucosamine was used to make the standard curve. The CHI specific activity is expressed in $\mu \mathrm{mol}$ of $\mathrm{N}$-acetyl-glucosamine per hour per $\mathrm{mg}$ of protein ( $\mu$ mole $\mathrm{N}$-acetyl-glucosamine. $\left.\mathrm{h}^{-1} \cdot \mathrm{mg}^{-1} \mathrm{P}\right)$.

Statistical analysis: Statistical analysis of enzyme activities was carried out with $\mathrm{R}$ program using one-way ANOVA with significance level $(p)$ of 0.05. Further analysis was carried out using the LSD test (Gomez and Gomez, 1984). Correlation coefficients were generated using $\mathrm{R}$ program. The error bars in the figures represent standard errors of means.

\section{RESULTS AND DISCUSSION}

Growth of rubber seedlings and white root disease symptom assessment: A number of studies have reported that fungal infection suppressed the growth of plant infected with the pathogen. Table 2 shows the height, diameter, and number of whorls for the six rubber clones, after 8 months of post inoculation with $R$. microporus. Based on the growth parameters of these rubber seedlings, there were significant differences, RRIM 600 and BPM 24 growths were below the others (Table 2).

Table 2 The growth of six cultivated rubber seedlings at 8 months after inoculation with $R$. microporus and without inoculation (control)

\begin{tabular}{lcccccc}
\hline \multirow{2}{*}{ Clone } & \multicolumn{5}{c}{ Growth parameter } \\
\cline { 2 - 7 } & Inoculated & Control & Inoculated & Control & \multicolumn{2}{c}{ Number of whorl } \\
& $104.9 \pm 5.6 \mathrm{ab}$ & $113.5 \pm 6.4 \mathrm{~b}$ & $12.2 \pm 0.0 \mathrm{ab}$ & $12.0 \pm 0.6 \mathrm{a}$ & $5.7 \pm 0.8 \mathrm{ab}$ & $7.0 \pm 0.4 \mathrm{a}$ \\
\hline RRIT 251 & $78.4 \pm 5.8 \mathrm{~b}$ & $148.4 \pm 5.6 \mathrm{ab}$ & $7.1 \pm 0.6 \mathrm{bc}$ & $14.4 \pm 0.4 \mathrm{a}$ & $4.9 \pm 0.2 \mathrm{~b}$ & $7.8 \pm 0.4 \mathrm{a}$ \\
RRIM 600 & $11.5 \pm 9.5 \mathrm{a}$ & $129.7 \pm 5.3 \mathrm{~b}$ & $12.9 \pm 1.4 \mathrm{a}$ & $10.9 \pm 0.4 \mathrm{a}$ & $5.4 \pm 0.3 \mathrm{ab}$ & $7.2 \pm 0.4 \mathrm{a}$ \\
RRIM 623 & $113.5 \pm 7.9 \mathrm{a}$ & $163.4 \pm 7.3 \mathrm{a}$ & $10.5 \pm 0.9 \mathrm{abc}$ & $13.3 \pm 0.4 \mathrm{a}$ & $6.1 \pm 0.4 \mathrm{a}$ & $7.0 \pm 0.5 \mathrm{a}$ \\
PB 5/51 & $86.3 \pm 6.6 \mathrm{ab}$ & $146.5 \pm 9.7 \mathrm{a}$ & $8.2 \pm 0.9 \mathrm{bc}$ & $12.6 \pm 0.4 \mathrm{a}$ & $4.7 \pm 0.3 \mathrm{~b}$ & $7.2 \pm 0.6 \mathrm{a}$ \\
BPM 24 & $94.4 \pm 3.6 \mathrm{ab}$ & $131.3 \pm 29.7 \mathrm{ab}$ & $10.9 \pm 1.0 \mathrm{abc}$ & $10.7 \pm 0.7 \mathrm{a}$ & $5.6 \pm 0.2 \mathrm{ab}$ & $6.0 \pm 0.5 \mathrm{a}$ \\
RRIT 408 & &
\end{tabular}

Different letters in each column indicate the significantly difference $(p<0.05)$ by LSD multiple range test. All data were presented as mean \pm S.E. calculated from three independent replicates.

The inoculated RRIM 600 showed the least height and diameter, followed by BPM 24 and RRIT 408. On the other hand, inoculated RRIM 623, PB 5/51, and RRIT 251 showed better growth performance than the others. The growth of inoculated rubber seedlings was obviously suppressed compared to control without inoculation as shown in Fig. 1. The height of the inoculated seedlings was clearly reduced by 7.58 to $47.20 \%$ compared to the control, and the diameter was suppressed by 21.11 to 50.94 $\%$. The height, diameter, and number of whorls of infected RRIM 600 were the most inhibited compared to control (by $47.20 \%, 50.94 \%$, and $37.31 \%$, respectively), followed by BPM 24. 


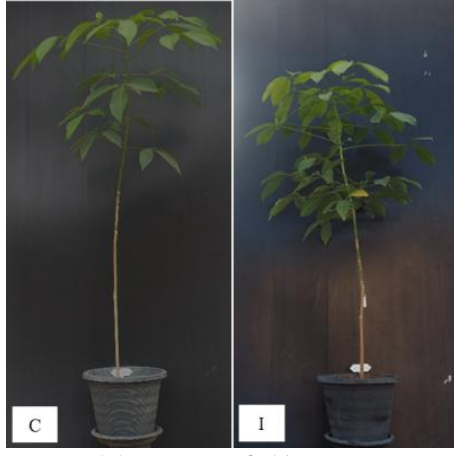

(a) RRIT 251

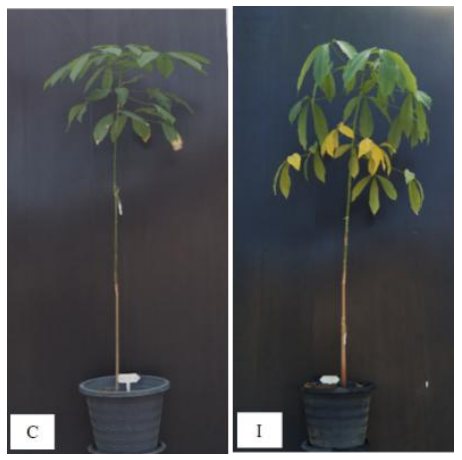

(d) RRIT 408

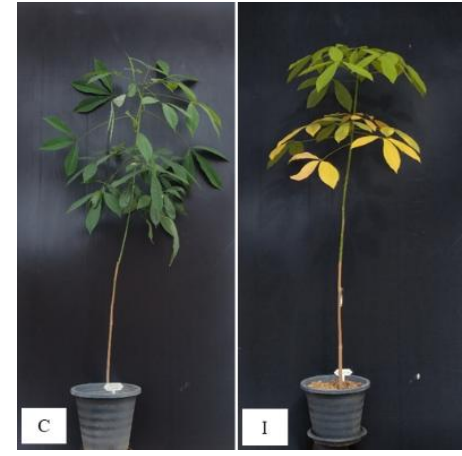

(b) RRIM 600

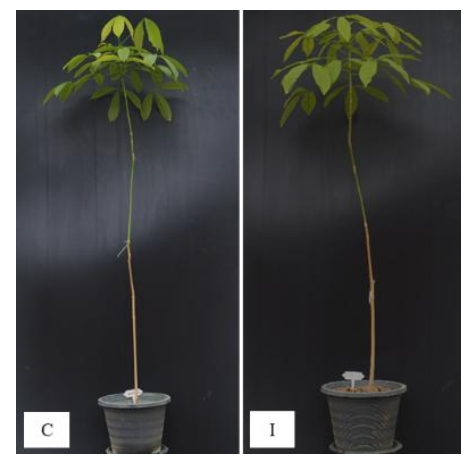

(e) PB 5/51

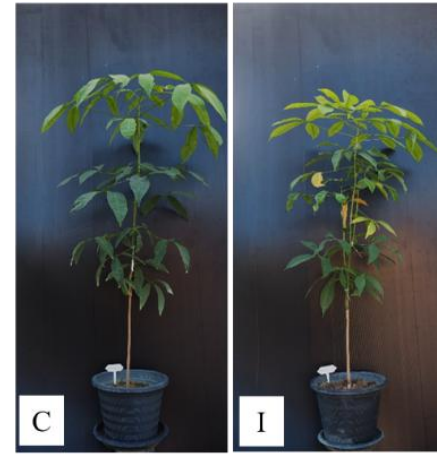

(c) RRIM 623

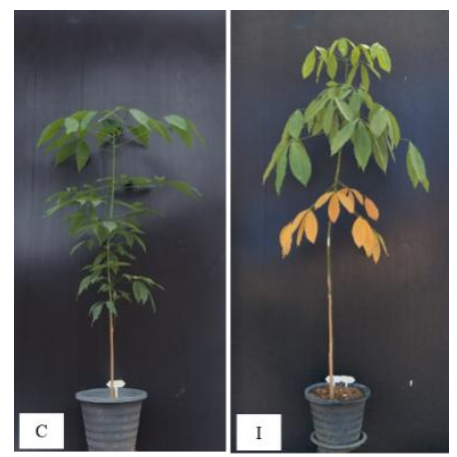

(f) BPM 24

Figure 1: Morphology of six clonal varieties of rubber, cultivated to 8-month-old seedlings, in two conditions: $\mathrm{C}$ is the control without inoculation with pathogen, while I means inoculated with $R$. microporus.

The disease index of each rubber rootstock was measured by scoring yellowish leaves. A number of rootstocks showed the disease symptoms few months after fungal inoculation, such as yellowish leaves appeared at 3 months post inoculation (mpi) on RRIM 600, while the other cultivated rubber seedlings, RRIT 251, RRIM 623, PB 5/51 showed less yellowish leaves (disease score was less than 3 ). The symptoms tended to become more severe by six to nine mpi. The disease indexes of BPM 24, RRIT 408, and RRIM 600 were over $30 \%$ (31.4, 36.7 and $37.8 \%$ respectively) at $8 \mathrm{mpi}$, slightly higher than of other tested clones. Meanwhile, RRIT 251, PB 5/51, and RRIM 623 rootstocks showed less yellowish leaves $(\leq 25.7 \%)$, respectively. Our study revealed that PB 5/51, RRIM 623, and RRIT 251 clones are comparatively tolerant to WRD, with a low disease incidence (25\%) and high defense-related enzyme activity. At the end of the investigation period, all the cultivated rubber rootstocks were alive, and even RRIM 600 was for 88.9 $\%$ definitely alive (Table 3 ).

Table 3: Disease index and survival rate of six rubber clones cultivated to seedlings at 9 months post inoculation with $R$. Microporus

\begin{tabular}{ccc}
\hline Clone & $\begin{array}{c}\text { Disease } \\
\text { index (DI) }\end{array}$ & $\begin{array}{c}\text { Survival rate } \\
(\%)\end{array}$ \\
\cline { 2 - 3 } & 25.7 & 100.0 \\
RRIT 251 & 37.8 & 88.9 \\
RRIM 600 & 24.4 & 100.0 \\
RRIM 623 & 25.0 & 100.0 \\
PB 5/51 & 31.4 & 100.0 \\
BPM 24 & 36.0 & 100.0 \\
RRIT 408 &
\end{tabular}

In our study, the symptoms of infected rubber trees were similar to prior reports (Farid et al., 2009; Kaewchai \& Soytong, 2010; Nakaew et al., 2015), according to which the symptoms include yellowing of leaves at 7-12 weeks after infection, wilting, burned leaves, and defoliation at 13-14 weeks, followed by white mycelium strands or rhizomorphs accumulating on lateral roots, producing fruit bodies and causing death of plant. A study conducted by (Kaewchai \& Soytong, 2010) found that 5-month-old RRIM 600 showed the symptoms at 70 days after inoculation, while Wattanasilakorn et al. (2012) reported that yellowing of leaves in 5month-old RRIM 600 clones appeared at 112 days, and the survival rate was below $33 \%$ at 5.5 months after infection. They concluded that the RRIM 600 is sensitive to WRD. Different times of symptom appearance in the same clone might be due to variations in fungal virulence by the specific strain tested. Also environmental conditions might be a contributing factor. Prasannath (2017) mentioned that 
soil characteristics (physical, chemical, and biological) are strongly related to WRD incidence. Moreover, the heterogeneity of seedlings in rubber root stocks, due to open pollination, may be another factor affecting disease resistance.

Defense-related gene expression: To optimize the specific primers for qRT-PCR analysis, the amplification efficacy of each primer was examined. The transcript level of PRIa in all six rubber clones was significantly induced at $1 \mathrm{dpi}$ (Fig. 2A). The transcript level of PRIa in RRIM 623 and PB 5/51 was initially upregulated at 1 and 3 dpi compared to the others, and the peak level was at $3 \mathrm{dpi}$ (4.7 and 2.6 fold upregulation, respectively), and subsequently downregulated at 5 and $7 \mathrm{dpi}$. In RRIT 408, the $P R$ $1 a$ transcript level was early induced at $1 \mathrm{dpi}$, and then continuously decreased at 3,5, and $7 \mathrm{dpi}$. Meanwhile the transcript level of PRla gene in other clones, RRIT 251, RRIM 600 and BPM 24 was varied. These PRla transcript levels reached the peak level at different times (RRIT 251 was at $5 \mathrm{dpi}$, RRIM 600 was at $3 \mathrm{dpi}$, and BPM 24 was at $7 \mathrm{dpi}$. Various transcriptional studies have reported upregulated $P R$ genes in plants after fungal infection (Ali et al., 2018). The gene expression of $P R I$ in para rubber infected by $R$. microporus increases disease resistance (Oghenekaro et al., 2016; Sangsil et al., 2016; Woraathasin et al., 2017a). In this study, PRla expression was not significantly elevated during fungal infection, but PRla gene expression in RRIM 623 and RRIT 251 was higher than in the other clones. PRIa gene expression was not induced in PB 5/51, which is known as a tolerant clone (Woraathasin et al., 2017a).

Transcript level of $P R 3$ gene in the six varieties of cultivated rubber seedlings, infected with $R$. microporus, is shown in Fig. 2B. The pattern of transcript fold changes did not significantly differ between the six clonal varieties, after inoculation with $R$. microporus. There was a steady pattern of $P R 3$ transcript levels. The $P R 3$ gene expression in RRIM 623 and PB 5/51 was elevated at 1 and 3 dpi with the peak at $3 \mathrm{dpi}$, and then the transcript level decreased at 5 and $7 \mathrm{dpi}$. The $P R 3$ transcript level in RRIT 251 and RRIM 600 showed peaks at 1 and 7 dpi, respectively. The transcript level in BPM 24 was steady with 1.1 to 1.89 fold upregulation. Although the level of transcription of PR3 showed no significant differences, the PB 5/51 infected seedlings showed the highest $P R 3$ upregulation at 3 dpi (5 fold). Commonly, PR3 protein known as chitinase, which contributes to the defense response to fungal infection. $P R 3$ gene was initially induced by phytopathogens through the jasmonate-signaling pathway, leading to SAR in the plant infected by a necrotrophic pathogen (Ali et al., 2018). Woraath- asin et al. (2017a) reported the $H b P R 3$ gene was induced in both a tolerant clone (PB 5/51) and in susceptible clones (RRIM 600 and BPM 24) after infection by $R$. microporus. According to Upadhyay et al (2014), interaction between Alternaria solani and tomato have induced PR3 genes in early infection. The chitinase gene are also early accumulated at $2 \mathrm{~h}$ and was significantly increased at $4 \mathrm{~h}$, $8 \mathrm{~h}, 24 \mathrm{~h}$, and $48 \mathrm{~h}$ upon Alternaria brassica infection in Brassica juncae (Rawat et al., 2017).

The expression of $P R 5$ gene in RRIM 623, PB $5 / 51$, and RRIT 408 reached the maximum level at 3 dpi (40, 31, and 23 folds, respectively). However, transcript level of the PR5 in those three infected seedlings gradually decreased by $5 \mathrm{dpi}$ and further by 7 dpi (Fig. 2C). The PR5 transcript level of RRIT 251 and RRIM 600 was similar in pattern, where the PR5 gene was early induced at $1 \mathrm{dpi}$, continuously decreased by 3 and $5 \mathrm{dpi}$, and increased at 7 dpi. Meanwhile, the BPM 24 clone inoculated with pathogen showed a constant level of transcription of $P R 3$ in the observations. A number of observations have proven that the transcript level of PR5 is clearly induced by a fungal infection (Guo et al., 2016; Oghenekaro et al., 2016; Wang et al., 2010), but not by a bacterial infection (Liu et al., 2013). The PR5 gene was strongly upregulated in the incompatible interaction during pathogen invasion (Wang et al., 2010). Oghenekaro et al. (2016) and Woraathasin et al. (2017b) agreed that R. Microporus infection in rubber clones significantly induced $P R 5$ that was highly expressed in tolerant clones. Various reports have shown that $P R 1, P R 3$, and $P R 5$ genes are involved in the activation of SA and/or JA pathways, as well as in the activation of SAR inducible defense program (Ali et al., 2018; Wang et al., 2010;). Meanwhile, according to Bonasera et al. (2006), PR1, PR2, PR5, and PR8 genes are not markers implicating SAR in young apple shoots. Based on these reports, the $P R$ genes' expression may differ by the host plant (Guo et al., 2016), and those $P R$ genes are diversely expressed depending on the tissue or organ (Liu et al., 2013).

$P A L$ gene contributes in phenylpropanoid pathway initiated from L-phenylalanine to transcinnamate leading to synthesis of antimicrobial compounds and cell wall strengthening. The $P A L$ gene was investigated as potential plant defense response, when challenged by a pathogen. In this study, $P A L$ gene expression in the rubber seedlings was determined at particular times after challenge by inoculation. Between the observation time points $(1,5$, and $7 \mathrm{dpi})$ there were significant differences in $P A L$ transcript level. The results show that $P A L$ gene expression in RRIM 600, RRIT 408 and RRIT 251 was down regulated initially by the infe- 
ction, except that RRIM 600 was upregulated at 1 dpi and RRIT 251 at 7 dpi. The PAL gene was highly expressed in PB 5/51 clone with peak at 1 dpi (2.9 fold), while the transcript level of $P A L$ in PB 5/51 slightly decreased with time. The BPM 24 seedlings presented the highest $P A L$ upregulation among the clones at 5 dpi (3.3 fold), with a decrease at 7 dpi (Fig. 2D). PAL gene is more expressed in a tolerant rubber clone than in a susceptible one, with some pathogen infections (Ngobisa et al., 2016; Oghenekaro et al., 2016; Sangsil et al., 2016). Our results on $P R 3, P R 5$ and $P A L$ genes are in agreement with those of Sayari et al. (2014) who evaluated the transcription level of the $P R 3, P R 5$ and $P A L$
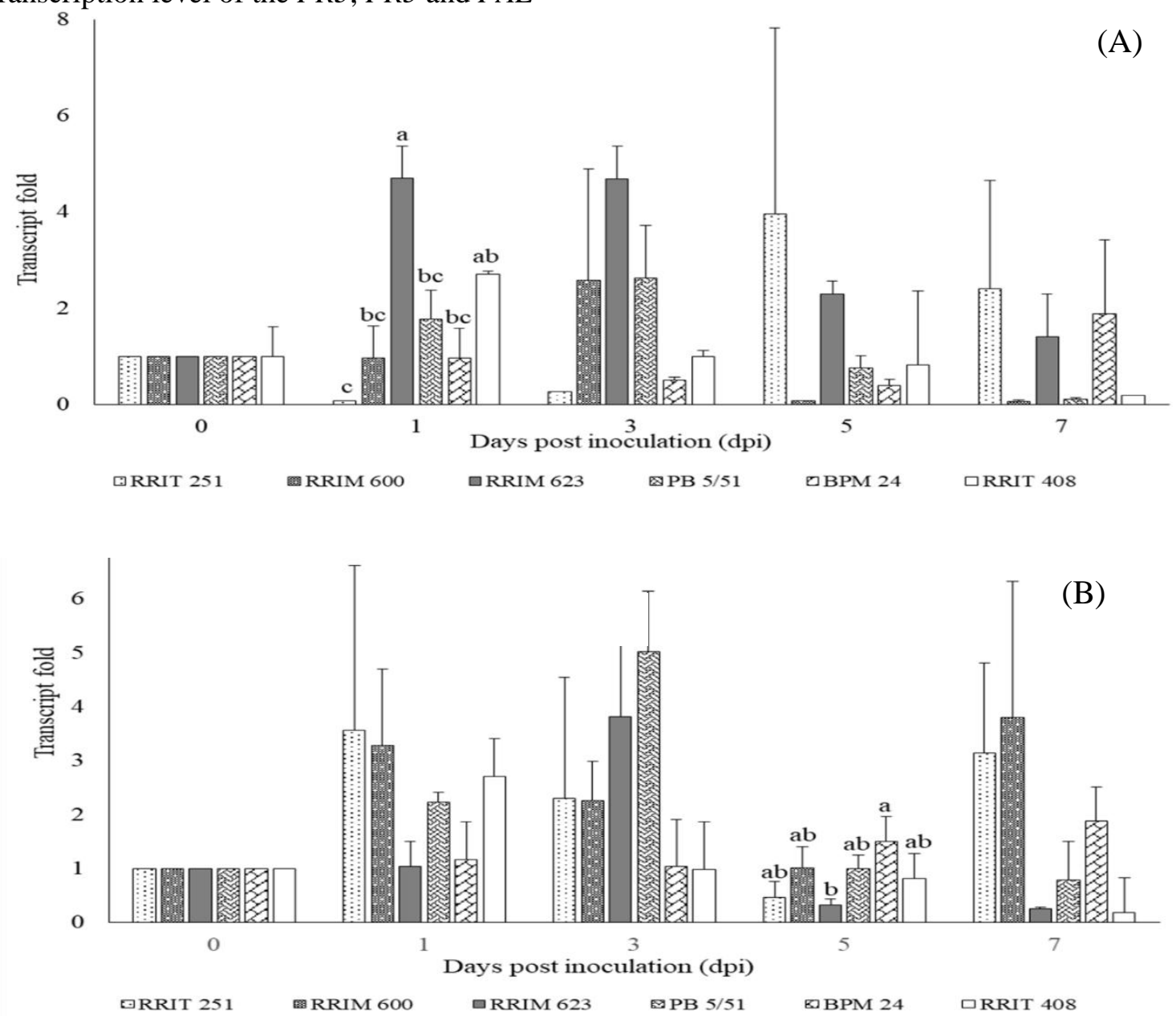

genes between resistant (Tarom) and susceptible (Khazar) rice cultivars in response to inoculation with Rhizoctonia solani. The results showed that $P R 3, P R 5$ and $P A L$ genes continued to accumulate up to 24-48 hours after inoculation in resistant genotype. The expression of those genes in susceptible genotype was not noticeable. In both roots and leaves of the resistant Brassica napus line, phenylpropanoid pathway genes were upregulated at more time points and at higher levels than in susceptible lines (Irani et al., 2019). 

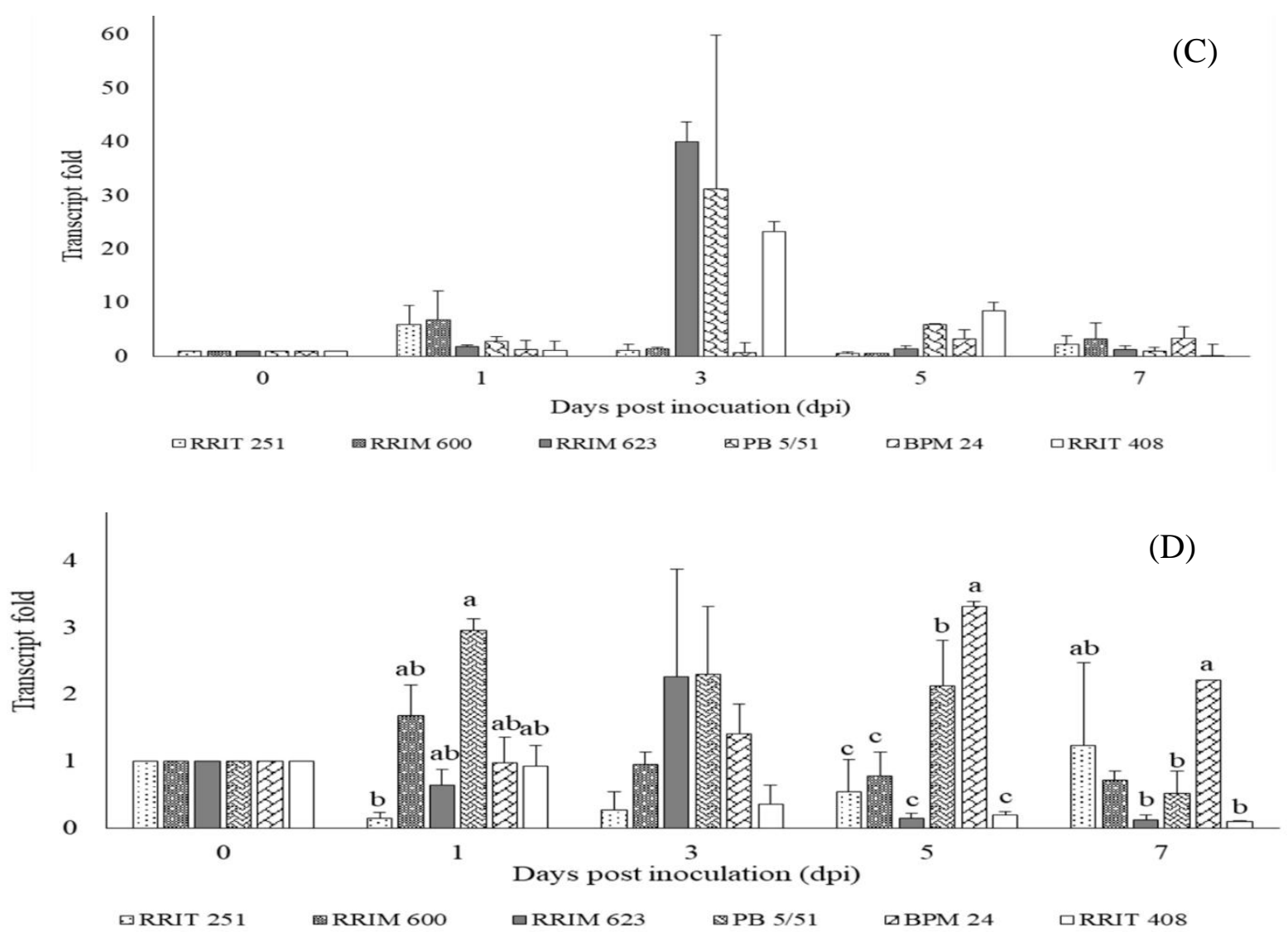

Figure 2: The $P R$ and $P A L$ transcript levels in six rubber clones. Fold change after inoculation with $R$. microporus: PRla (A), PR3 (B), PR5 (C) and PAL (D). All the data are presented as mean \pm S.E. calculated from three independent replicates.

Activity of key enzymes related to phenylpropanoid and PR protein pathways: Rubber seedlings treated with $R$. microporus were investigated for 7 days, and the CHI, PAL, and POD enzyme activities were assayed. Fig. 3A shows the CHI activity in the six cultivated types of rubber seedlings after inoculation with $R$. microporus. The patterns of CHI activity were not consistent between the clonal varieties. In the normal condition $(0$ dpi), CHI had a low activity level (0.196-0.352 $\mu$ mole $\mathrm{N}$-acetyl-D-glucosamine. $\mathrm{h}^{-1} \mathrm{mg}^{-1} \mathrm{P}$, respecttively), but was induced subsequently at 3 dpi with $32.5-105 \%$ increase in activity, except for BPM 24 in which the activity was reduced by $9 \%$. Infected BPM 24 seedlings also showed the lowest CHI activity at all observation time points. PB 5/51 showed the highest $\mathrm{CHI}$ activity that steadily increased at 1 and 3 dpi (26 to $62 \%$ compared to $0 \mathrm{dpi}$, respectively), and subsequently decreased at 5 and 7 dpi. Our results showed different $\mathrm{CHI}$ activity patterns in the six rubber clones. However, CHI in BPM 24 seemed less active at all observed times during infection. Xu et al. (2016) reported that CHI in plants is a crucial enzymes that catalyze fungal cell wall degradation. A number of studies have reported that the $\mathrm{CHI}$ are important for disease resistance. Increased CHI and GLU activities in infected grapevine leaves were plant resistance responses to insults with Uncinula necator (Giannakis et al., 1998). In addition, chitinase activity showed significant increase in roots and leaves of oil palm seedling at two weeks post infection with $G$. boninense (Naher et al., 2012).

The PAL activities in six cultivated rubber seedlings inoculated with $R$. microporus are presented in Fig. 3B. The PAL activity in infected rubber seedlings was clearly affected at 0,3 , and 7 dpi. At 0 dpi (uninoculated seedlings), the PAL activity was $0.19-0.33$ mol trans-cinnamic acid.h ${ }^{-}$ ${ }^{1} . \mathrm{mg}^{-1} \mathrm{P}$. The lowest PAL activity was in PB 5/51, whereas the highest was in RRIM 600 and BPM 24. PB 5/51 showed the most PAL accumulation during the observations. At $1 \mathrm{dpi}$, mostly PAL activity had decreased, but then reached the maximum level at 3 dpi,peaking at $37.7 \%-401.0 \%$ compared to 0 dpi. The highest PAL activity at 3 dpi was in PB $5 / 51$, followed in rank order by RRIT 251, RRIM 623, and RRIT $408(0.990,0.821,0.623$, and 0.611 mol trans-cinnamic acid. $\mathrm{h}^{-1} \cdot \mathrm{mg}^{-1} \mathrm{P}$, respectively). Moreover, those enzyme activities decreased at 5 dpi in all the cultivated rubber seedlings, but increased gradually at $7 \mathrm{dpi}$. According to Slatnar et al. (2010), activity of PAL enzyme was induced in apple by a scab spot infection with Ventyria inae- 
qualis, over healthy peels, and the fungal infection increased metabolism of phenolic compounds. Other enzymes, such as POD, also contribute in phenylpropanoid pathways, and play an important role in plant defense against both necrotrophic and /or biotrophic pathogens (Van Loon et al., 2006). The POD is involved in reinforcement of cell walls, ferulic acid cross-linking, lignification, and suberization and metabolism of ROS, in plant defense responses (Almagro et al., 2008). Ma et al. (2018) reported the PAL, $4 \mathrm{CL}, \mathrm{CAD}$ and $\mathrm{C} 4 \mathrm{H}$ are linked to phenylpropanoid metabolism, which is probably associated with apple fruit resistance to grey mould disease. In this study, the POD activity was initally induced after inoculation, at $1 \mathrm{dpi}$. The pattern of POD activity was similar as with PAL activity. The POD activity was significantly elevated and reached its maximum at $3 \mathrm{dpi}$, as presented in Fig. 3C. The PB 5/51-rubber seedlings inoculated with $R$. microporus showed the highest POD activity at 1 , 3, 5 and 7 dpi among all the clones. The highest POD activity was detected at 3 dpi in PB 5/51 clone $\left(1,314.7\right.$ Unit. $\left.\mathrm{mg}^{-1} \mathrm{P}\right)$. The POD activities in other infected clones were around 311-601 Unit. $\mathrm{mg}^{-1} \mathrm{P}$ respectively. The fungal inoculation in BPM 24 induced POD activity early, but this clone had the lowest activity among all the cases.
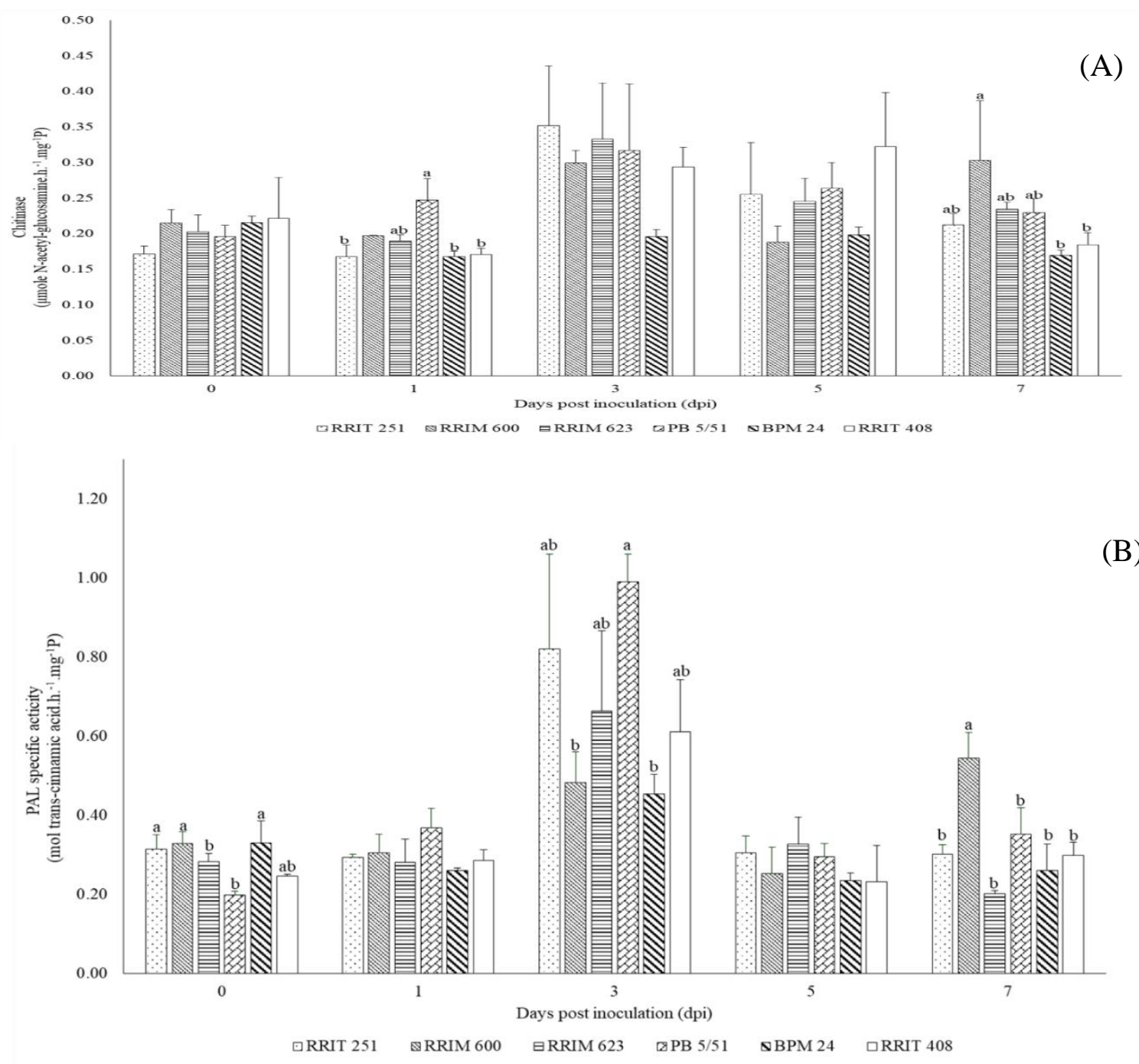

(B) 


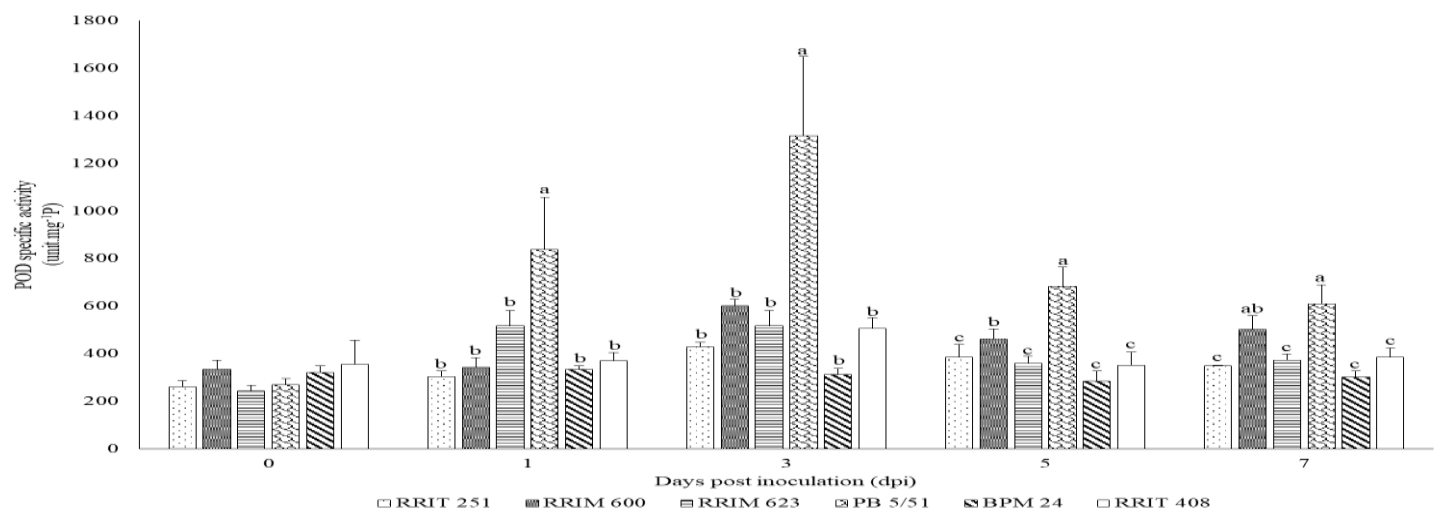

Figure 3: Defense-related enzyme activities in six rubber clones after inoculation with $R$. microporus: Chitinase (A), Phenylalanine ammonia lyase (B), and Peroxidase (C). All the data are presented as mean \pm S.E. calculated from three independent replicates.

Currently, there are rubber rootstocks with partial tolerance to WRD and significant efforts are in progress to select material with enhanced tolerance and other agronomic traits. In addition, investigations are underway to gain a better knowledge of the Hevea-R.micoporus interaction with the objective of developing tools that could be used to speed up rubber rootstock breeding and selection programmes. Along this line, early introduced rubber clones were screened by shoot growth, root development and physiological response after inoculation with WRD and it was found that there were some clones that exhibited tentative tolerance to WRD (Wattanasilakorn et al., 2012). Approximately 150 days are required from inoculation until the appearance of visible aboveground symptoms assessment in this conventional system. A decrease in time, labor, and inputs makes the laboratory assays through gene expression and enzyme activities, suitable tools for shortening the breeding program of WRD tolerance. Examining rubber gene expression profiles in contrasting disease reactions will contribute to a better understanding of the molecular interactions underlying tolerance and susceptibility to WRD and would allow the identification of new genes that could be used as markers in rubber rootstock breeding programmes. Taken together, field evaluation through visual observation and laboratory assays through gene expression and enzyme activities have led to screening of putatively tolerant rubber clones. This study represents the first report on gene expression and enzyme activities analysis for assessing the response of tolerant and susceptible rubber rootstocks to WRD. Based on observed transcriptional level of $P R s$ and $P A L$ genes, CHI, PAL, and POD enzyme activities, and also evidence from WRD symptom assessment in the field, we conclude that PB 5/51, RRIM 623, and RRIT 251 clones are rubber clones comparatively tolerant to the WRD, while the BPM 24,
RRIM 600 and RRIT 408 clones are moderately susceptible to WRD.

\section{Acknowledgments}

This work was supported by a grant from Natural Rubber Innovation Research Institute, Prince of Songkla University (Grant No. NAT6003915). The authors would like to thank Assoc. Prof. Seppo Karrila from the Publication Clinic, Research and Development Office, Prince of Songkla University, for technical comments and improving the manuscript.

\section{REFERENCES}

Ali, S., Ganai BA, A.N. Kamili, A.A. Bhat,Z.A. Mir, J.A. Bhat, A. Tyagi, S.T. Islam, M. Mushtaq, P. Yadav, S. RawatandA. Grover, Pathogenesis-related proteins and peptides as promising tools for engineering plants with multiple stress tolerance. Microbiol. Res. 212: 29-37 (2018).

Almagro, L., R.L. Gómez, S. Belchi-Navarro, R. Bru, A. Ros Barceló and M.A. Pedreño,Class III peroxidases in plant defence reactions. J. Exp. Bot. 60: 377-390 (2008).

Assis, J.S, R.Maldonado, T. Muñoz, M.I. Escribano and C. Merodio, Effect of high carbon dioxide concentration on PAL activity and phenolic contents in ripening cherimoya fruit. Postharvest Biol. Technol. 23: 33-39 (2001).

Bonasera, J.M., J.F. Kim and S.V. Beer, PR genes of apple: identification and expression in response to elicitors and inoculation with Erwinia amylovora. BMC Plant Biol. 6: 23 (2006).

Bradford, M.M., A rapid and sensitive method for the quantitation of microgram quantities of protein utilizing the principle of protein-dye binding. Anal. Biochem. 72: 248-254 (1976).

Chandrasekaran, M., S.T. Belachew, E. Yoon and S.C. Chun, Expression of $\beta$-1,3-glucanase $(G L U)$ and phenylalanine ammonia-lyase $(P A L)$ genes and their enzymes in tomato 
plants induced after treatment with Bacillus subtilis CBR05 against Xanthomonas campestris pv. vesicatoria. J. Gen. Plant Pathol. 83: 713 (2017).

Deng, L.H., M.W. Luo, C.F. Zhang and H.C. Zeng, Extraction of high-quality RNA from rubber tree leaves. Biosci Biotechnol. Biochem. 76: 1394-1396 (2012).

Fajardo, J., T. McCollum, R. McDonald and R.T. Mayer, Differential Induction of Proteins in Orange Flavedo by Biologically Based Elicitors and Challenged by Penicillium digitatum Sacc. 1. Biol. Control 13: 143-151 (1998).

Farid, A.M., S. Lee, Z. Maziah andM. Patahayah, Pathogenicity of Rigidoporus microporus and Phellinus noxius against four major plantation tree species in peninsular Malaysia. J. Trop. For. Sci. 2: 89-298 (2009).

Ferreira, R.B., S. Monteiro, R. Freitas, C.N. Santos, Z. Chen, L.M. Batista, J. Duarte, A. Borges andA.R. Teixeira, The role of plant defence proteins in fungal pathogenesis. Mol. Plant Pathol. 8: 677-700 (2007).

Giannakis, C., C. Bucheli, K. Skene, S.P. Robinson andN. Steele Scott, Chitinase and $\beta$ - 1, 3glucanase in grapevine leaves: a possible defence against powdery mildew infection. Aust. J. Grape Wine Res. 4: 14-22 (1998).

Gomez, K.A. and A.A. Gomez, Statistical procedures for agricultural research (2 ed.). John wiley and sons, NewYork, 680p. (1984).

Guo, J., X. Zhao, H. Wang, T. Yu, Y. Miao and X. Zheng, Expression of the LePR5 gene from cherry tomato fruit induced by Cryptococcus laurentii and the analysis of LePR5 protein antifungal activity. Postharvest Biol. Technol. 111: 337-344 (2016).

Irani, S., C.D. Todd, Y. Wei and P.C. BonhamSmith, Changes in phenylpropanoid pathway gene expression in roots and leaves of susceptible and resistant Brassica napus lines in response to Plasmodiophora brassicae inoculation. Physiol. Mol. Plant Pathol. 106: 196203(2019).

Jetiyanon, K, Defensive-related enzyme response in plants treated with a mixture of Bacillus strains (IN937a and IN937b) against different pathogens. Biol. Control 42: 178-185 (2007).

Kaewchai, S. and K. Soytong, Application of biofungicides against Rigidoporus microporus causing white root disease of rubber trees. J. Agri Tech.6: 349-363 (2010).

Kim, D.S. and B.K. Hwang, An important role of the pepper phenylalanine ammonia-lyase gene (PAL1) in salicylic acid-dependent signalling of the defence response to microbial pathogens. J. Exp. Bot. 65: 2295-2306 (2014).

Kumar, A., M.S. Hunjan, H. Kaur, H.K. Dhillon and P.P. Singh, Biochemical responses associated with resistance to bacterial stalk rot caused by Dickeya zeae in maize. J. Phytopathol. 165: 822-832 (2017).

Li, H., Y. Qin, X. Xiao and C. Tang, Screening of valid reference genes for real-time RT-PCR data normalization in Hevea brasiliensis and expression validation of a sucrose transporter gene HbSUT3. Plant Sci. 181: 132-139 (2011).

Liu, J., M. Wisniewski, T. Artlip, Y. Sui, S. Droby and J. Norelli, The potential role of PR-8 gene of apple fruit in the mode of action of the yeast antagonist, Candida oleophila, in postharvest biocontrol of Botrytis cinerea. Postharvest Biol. Technol. 85: 203-209 (2013).

Livak, K.J. and T.D. Schmittgen, Analysis of relative gene expression data using real-time quantitative PCR and the $2^{-\triangle \Delta C T}$ method. Methods 25: 402-408 (2001).

Ma, L., J. He and H. Liu, The phenylpropanoid pathway affects apple fruit resistance to Botrytis cinerea. J. Phytopathol. 166: 206-215 (2018).

Miller, G.L., Use of dinitrosalicylic acid reagent for determination of reducing sugar. Anal. Chem. 31: 426-428 (1959).

Montesinos, E., Pathogenic plant-microbe interactions: What we know and how we benefit. Int. Microbiol.3: 69-70 (2000).

Naher, L., S.G. Tan, U.K. Yusuf, C.L. Ho and S. Siddiquee, Activities of chitinase enzymes in the oil palm (Elaeis guineensis Jacq.) in interactions with pathogenic and non-pathogenic fungi. Plant Omics 5:333-336 (2012).

Nakaew, N., C. Rangjaroen and R. Sungthong, Utilization of rhizospheric Streptomyces for biological control of Rigidoporus sp. causing white root disease in rubber tree. European J. Plant Pathol. 142(1): 93-105 (2015).

Nandris, D., M. Nocoleand J.P. Geiger, Root rots disease of rubber tree. Plant Dis. 71: 298-306 (1987).

Nissapa, A. and S. Chuenchit, Economic loss assessments from white root disease in rubber in southern Thailand. Report of Faculty of Natural Resource, Prince of Songkla University. Pp. 277 (2011).

Ngobisa, A.N., G. Ntsomboh-Ntsefong, W.M. Yun, M.Z. Dzarifah and P.A. Owona Ndongo, Transcriptional expression of three putative pathogenesis-related proteins in leaves of rubber tree (Hevea brasiliensis) inoculated with 
Neofusicoccum ribis. J. Appl. Biol. Biotechnol. 4: 011-015 (2016).

Ogbebor, O.N., V.I. Omorusi, A.T. Adekunle, K. Orumwense and K. Ijieh, Fast method for the detection of Rigidoporus lignosus (Klotzsch) Imaz in Hevea Plantations. Int. J. Sci. Nat.4: 109-111 (2013a).

Ogbebor, N., A. Adekunle, O. Eghafona and A. Ogboghodo, Incidence of Rigidoporus lignosus (Klotzsch) imaz of para rubber in Nigeria. Researcher 5: 181-184 (2013b).

Oghenekaro, A., V. Omorusi and F. Asiegbu, Defence- related gene expression of Hevea brasiliensis clones in response to the white rot pathogen, Rigidoporus microporus. For. Pathol. 46: 318-326 (2016).

Pawirosoemardjo, S., H. Soepena and A. Situmorang, Sebaran penyakit utama tanaman karet di Indonesia. Lokakarya Nasional Pemuliaan Tanaman Karet, Medan, 7-0 (1992).

Prasannath, K., Plant defense-related enzymes against pathogens: a review. AGRIEAST: J. Agric. Sci. 11(1) (2017).

Rawat, S., S. Ali, B. Mittra and A. Grover, Expression analysis of chitinase upon challenge inoculation to Alternaria wounding and defense inducers in Brassica juncae. Biotechnol. Rep. 13: $72-79$ (2017).

Rojsujit, A., A. Juntarapratin, P. Romreunsukharom, N. Junrueng, S. Greethaphol, W. Preuksavivat, S. Preuksawarun, W. Sasiprapa, P. Kumput and P. Phongouttha, Assessment on economic loss of rubber production causing from white root disease (Rigidoporus microporus) in Thailand. Rubber Authority of Thailand 248-267 (2011).

Sangsil, P., C. Nualsri, N. Woraathasin and, K. Nakkanong, Characterization of the phenylalanine ammonia lyase gene from the rubber tree (Hevea brasiliensis Müll. Arg.) and differential response during Rigidoporus microporus infection. J. Plant Prot. Res. 56: 380-388 (2016).

Sayari, M., V. Babaeizad, M.A.T. Ghanbari and H. Rahimian, Expression of the pathogenesis related proteins, NH-1, PAL, and lipoxygenase in the iranian Tarom and Khazar rice cultivars, in reaction to Rhizoctonia solani the causal agent of rice sheath blight. J. Plant Prot. Res. 54: 35-43 (2014).

Slatnar, A., M. Mikulic Petkovsek, H. Halbwirth, F. Stampar, K. Stich and R.Veberic, Enzyme activity of the phenylpropanoid pathway as a response to apple scab infection. Ann. Appl. Biol. 156: 449-456 (2010).
Soytong, K. and S. Kaewchai, Biological control of white root of rubber trees using Chaetomium cupreum. Inter. J. Agric. Technol. 10: 93103(2014).

Upadhyay, P., A. Rai, R. Kumar, M. Singh and B. Sinha, Differential expression of pathogenesis related proteins genes in tomato during inoculation with A. Solani. J. Plant Pathol. Microb.5:217(2014).

Van Loon, L,C., M. Rep and, C.M. Pieterse, Significance of inducible defense-related proteins in infected plants. Annu. Rev. Phytopathol. 44: 135-162 (2006).

Wang, X., C. Tang and L. Deng L, Characterization of a pathogenesis- related thaumatin- like protein gene TaPR5 from wheat induced by stripe rust fungus. Physiol Plant 139: 27-38 (2010).

Wattanasilakorn, S., S. Sdoodee and C. Nualsri, Screening of rubber (Hevea brasiliensis Muell. Arg.) rootstocks for the white root disease resistance. J. Agric. Technol. 8: 2385-2395 (2012).

Wattanasilakorn, S., S. Sdoodee, C. Nualsri, S. Chuenchit, U. Meesawat and J. Sopharat, Assessment of Rubber Clonal Rootstocks for the Tolerance of White Root Disease (Rigidoporus microporus) in Southern Thailand. Walailak J. Sci.Technol. 14: 549-561 (2017).

Woraathasin, N., K. Nakkanong and C. Nualsri, Cloning and expression analysis of $H b P R-1 \mathrm{~b}$ and HbPR-3 in Hevea brasiliensis during inoculation with Rigidoporus microporus. Pak. J. Biol. Sci. 20: 233-243 (2017a).

Woraathasin, N., K. Nakkanong and C. Nualsri, Expression responses of pathogenesis-related proteins in tolerant and susceptible Hevea brasiliensis clones to the white root disease. Pakistan J. Biotechnol. 14: 141-148 (2017b).

Xu, J., X. Xu, L. Tian, G. Wang, X. Zhang, X. WangandW. Guo, Discovery and identification of candidate genes from the chitinase gene family for Verticillium dahliae resistance in cotton. Sci Rep 6: 29022 (2016).

Zhang, S., S. Lu and X. Xu, Changes in antioxidant enzyme activities and isozyme profiles in leaves of male and female Populus cathayana infected with Melampsora larici-populina. Tree Physiol. 30: 116-128 (2009). 